Regards sur l'économie allemande

Bulletin économique du CIRAC

$75 \mid 2006$

Varia

\title{
Etat social
}

BOECKH Jürgen, HUSTER Ernst-Ulrich, BENZ Benjamin, Sozialpolitik in Deutschland. Eine systematische Einführung

\section{(2) OpenEdition}

\section{Journals}

Édition électronique

URL : http://journals.openedition.org/rea/497

DOI : $10.4000 /$ rea. 497

ISBN : 978-2-8218-0846-1

ISSN : 1965-0787

Éditeur

CIRAC

Édition imprimée

Date de publication : 1 mars 2006

ISSN : 1156-8992

Référence électronique

«Etat social », Regards sur l'économie allemande [En ligne], 75 | mars 2006, document 5, mis en ligne le 24 avril 2008, consulté le 22 septembre 2020. URL : http://journals.openedition.org/rea/497 ; DOI : https://doi.org/10.4000/rea.497

Ce document a été généré automatiquement le 22 septembre 2020

(C) CIRAC 


\section{Etat social}

BOECKH Jürgen, HUSTER Ernst-Ulrich, BENZ Benjamin, Sozialpolitik in Deutschland. Eine systematische Einführung

\section{RÉFÉRENCE}

BOECKH Jürgen, HUSTER Ernst-Ulrich, BENZ Benjamin, Sozialpolitik in Deutschland. Eine systematische Einführung, VS Verlag für Sozialwissenschaften, Wiesbaden, 2004, $464 \mathrm{p}$.

1 L'Etat social a-t-il des limites? se demande ce manuel. Pour répondre, les auteurs retracent l'évolution du welfare state: de sa genèse dès avant Bismarck à l'émergence d'une approche sociale de l'intégration communautaire. Ils parviennent à la conclusion que sans politique sociale, la démocratie est impossible. Elle en est la condition sine qua non. (ib) 